\title{
Study of posterior vaginal wall prolapses and correlation with bowel function
}

\author{
Smita Anand Bijwe*, Pooja Rajbhara
}

Department of Obstetrics and Gynecology, Dr. PDMMC, Amravati, Maharashtra, India

Received: 02 April 2017

Revised: 15 May 2017

Accepted: 19 May 2017

\section{*Correspondence:}

Dr. Smita Anand Bijwe,

E-mail: dranandbijwe@gmail.com

Copyright: $\odot$ the author(s), publisher and licensee Medip Academy. This is an open-access article distributed under the terms of the Creative Commons Attribution Non-Commercial License, which permits unrestricted non-commercial use, distribution, and reproduction in any medium, provided the original work is properly cited.

\section{ABSTRACT}

Background: This study's objectives were to describe symptoms related to bowel symptoms in women with prolapse and to compare these symptoms as per the grading of posterior vaginal prolapse.

Methods: Descriptive study, 63 women answered questionnaire for assessment of bowel function and were subjected to physical examination according to the International Continence Society's system for grading uterovaginal prolapse. Results: The distribution of pelvic organ support by overall POPQ stage was $6.4 \%$ stage $1,21 \%$ stage $2,50 \%$ stage 3 , and $23 \%$ stage 4 . Women were asked to rate the extent to which they were bothered by their bowel function on a scale of 1 to 10 , with 1 being not at all and 10 being extremely. Thirty-six women (58\%) reported 1 to $4,18(29 \%)$ reported 5 to 7 , and $8(13 \%)$ reported greater than 8 . According to the furthest extent of posterior vaginal prolapse at point $\mathrm{Bp}$, $22(15.5 \%)$ were in stage $0,46(32.4 \%)$ were in stage I, $50(35.2 \%)$ were in stage II, $23(16.2 \%)$ were in stage III, and $1(0.7 \%)$ was in stage IV. Ninety-two percent of women reported having bowel movements at least every day. When asked whether straining was required for them to have a bowel movement, $67 \%$ reported never or rarely,3\% reported sometimes, $1.6 \%$ ) reported always. When asked whether they ever needed to help stool come out by pushing with a finger in the vagina or rectum, $77.0 \%$ reported never or rarely, $15.1 \%$ reported sometimes, $(5.6 \%)$ reported usually, and $(1.6 \%)$ reported always. No women had fecal incontinence, there were no clinically significant associations between any of the questions related to bowel function and severity of posterior vaginal prolapse.

Conclusions: Women with uterovaginal prolapse frequently have symptoms related to bowel dysfunction but this is not associated with the severity of posterior vaginal prolapse.

Keywords: Bowel Function, Correlation, Posterior vaginal wall prolapse

\section{INTRODUCTION}

Prolapse though not life threatening condition, severely affect quality of life in women causing physical, social, psychological, occupational, domestic limitations. ${ }^{1}$ The incidence of urogenital prolapse increases with advancing age, menopause and parity. ${ }^{2}$ It is estimated that $50 \%$ of parous women lose pelvic floor support and, as a result, develop prolapse, but only $20 \%$ of these women are symptomatic. Anorectal dysfunction is probably less understood pelvic symptom in women with prolapse.
These patients may experience pain with defecation, the need to splint or strain to have a bowel movement or anal incontinence. Meschia found a 2-fold increased risk of anal incontinence in patients with a rectocele greater than grade 2. Surgery is the definitive treatment.

It is estimated that the lifetime risk of undergoing at least one surgical procedure for prolapse is $11 \%$ and the reoperation rate for recurrent prolapse is $30-40 \% .^{3}$ The surgical indication should be based on the individual's symptoms rather than the degree of vaginal wall prolapse. 
Therefore, an accurate assessment of women suffering from posterior vaginal wall prolapse, requires subjective symptoms and objective findings evaluation for therapeutic management. The POP-Q system gained the attention of the specialists all over the world, being approved by the International Continence Society (ICS), the American Urogynecologic Society (AUGS), and the Society of Gynecologic Surgeons for the description of female pelvic organ prolapse. ${ }^{4-7}$ International Continence Society (ICS), established in 1971 is the most common system used by gynecologists and urogynecologists, although other systems have been devised. ${ }^{8}$

Aims and objectives of present work were to study bowel symptoms in women with pelvic organ prolapse, to compare the various pelvic symptoms to the severity of posterior vaginal wall prolapse and correlations between vaginal descent, bowel symptoms and POP-Q measurements among women with prolapse.

\section{METHODS}

Department of Obstetrics and Gynecology at teaching Hospital over one year duration, Study Design Descriptive study. Study population Women of all ages attending Gynaecology OPD with Pelvic organ Prolapse will be included in study after taking informed consent. Women with pregnancy and neurological disease will be excluded. The hymen acts as the fixed point of reference throughout the POPQ system.

There are six defined points for measurement in the POPQ system Aa, Ba, C, D, Ap, Bp and three others landmarks: GH, TVL, PB. Each is measured in centimeters above or proximal to the hymen (negative number) or centimeters below or distal to the hymen (positive number) with the plane of the hymen being defined as zero (0).

The hymen was selected as the reference point rather the introitus because it is more precisely identified. 8 There are three reference points anteriorly ( $\mathrm{Aa}, \mathrm{Ba}$, and $\mathrm{C}$ ) and three posteriorly (Ap, Bp, and D). Points Aa and Ap are 3 $\mathrm{cm}$ proximal to or above the hymenal ring anteriorly and posteriorly, respectively. Points $\mathrm{Ba}$ and $\mathrm{Bp}$ are defined as the lowest points of the prolapse between Aa anteriorly or Ap posteriorly and the vaginal apex. Anteriorly, the apex is point (cervix), and posteriorly is point $\mathrm{D}$ (pouch of Douglas). In women after hysterectomy, point $\mathrm{C}$ is the vaginal cuff and point $\mathrm{D}$ is omitted.

Three other measurements are taken: the vaginal length at rest, the genital hiatus (gh) from the middle of the urethral meatus to the posterior hymenal ring, and the perineal body $(\mathrm{pb})$ from the posterior aspect of the genital hiatus to the midanal opening. The bowel symptoms considered were difficulty in defecation (distal stool trapping or excessive straining to empty the bowels), feeling of incomplete bowel emptying, constipation and manual evacuation (digital assistance).

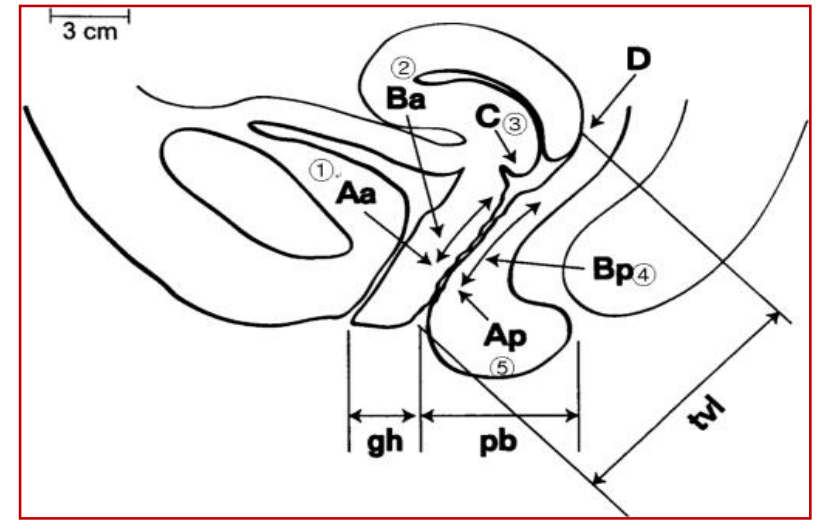

Figure 1: POP-Q (pelvic organ prolpase quantification measurements).

\section{RESULTS}

Sixty-two women were recruited to participate in the study over a 12-month period.

Table 1: Distribution on basis of occupation.

\begin{tabular}{|lll|}
\hline Occupation & N & $\%$ \\
\hline Housewife & 28 & 45 \\
\hline Labourer & 25 & 40 \\
\hline Farmer & 4 & 6.4 \\
\hline Nursery & 3 & 4.8 \\
\hline Shopkeeper & 1 & 1.6 \\
\hline Medical staff & 1 & 1.6 \\
\hline Total & 62 & 100 \\
\hline
\end{tabular}

The mean age for the women was 50 years (range18-82 years). Thirty eight of 62 women (61\%) were postmenopausal. A urogenital prolapse was defined and explained to the women, on the front page of the questionnaire, as a bulge coming down the vagina causing discomfort.

Table 2: Distribution of subjects based on parity.

\begin{tabular}{|lll|}
\hline Parity & N & $\%$ \\
\hline 1 & 4 & 6.0 \\
\hline 2 & 14 & 23.0 \\
\hline 3 & 21 & 34.0 \\
\hline 4 & 13 & 21.0 \\
\hline 5 & 5 & 8.0 \\
\hline 6 & 3 & 4.80 \\
\hline 7 & 1 & 1.60 \\
\hline 8 & 1 & 1.60 \\
\hline Total & 62 & 100.0 \\
\hline
\end{tabular}

The severity of P-QOL was strongly correlated with the vaginal examination findings. Spearman's rank correlation analysis confirmed that the questionnaire items, designed to assess the effect of the prolapse symptoms on quality of life, correlated with the objective vaginal examination findings. 
Most of the females were between 40-50 years of age (37\%), while patients beyond 60 years were around $17 \%$.

Table 3: Distribution on basis of cystocele, rectocele, enterocele.

\begin{tabular}{|lll|}
\hline Associated signs & N & $\%$ \\
\hline Cystocele & 42 & 67.7 \\
\hline Rectocele & 15 & 24.1 \\
\hline Enterocele & 19 & 30.6 \\
\hline
\end{tabular}

Women were asked to rate the extent to which they were bothered by their bowel function on a scale of 1 to 10 , with 1 being not at all and 10 being extremely.

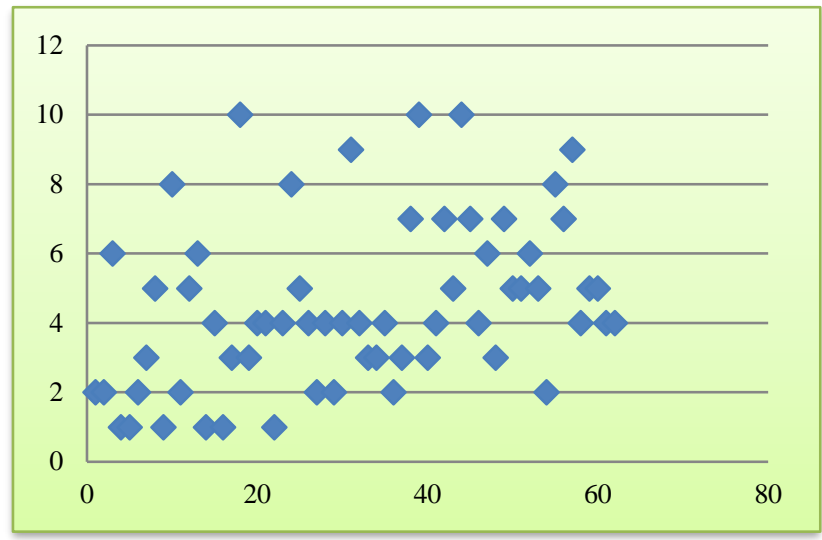

Figure 2: Bowel 1-10 scale.

Thirty-six women (58\%) reported 1 to $4,18(29 \%)$ reported 5 to 7 , and $8(13 \%)$ reported and gt; 8.22 $(35.4 \%)$ reported having bowel movements more than once a day, $29(46.8 \%)$ once a day, $8(13 \%)$ once every 2 day, $2(3.2 \%)$ every 3 rd day, $1(1.6 \%)$ once a week.

Twelve women (8.5\%) had bowel movements less frequently than every other day.

When asked whether they ever needed to help stool to come out by pushing with a finger in the vagina or rectum, $48(77.4 \%)$ reported never or rarely, $9(14.5 \%)$ reported sometimes, $4(6.4 \%)$ reported usually, and 1 $(1.6 \%)$ reported always. Neither of the patient had fecal incontinence or gaseous incontinence.

Bowel symptoms showed poor correlation with anterior, apical and posterior wall prolapse. Protrusion symptom severity was also correlated with anterior, apical posterior wall prolapse. Severity of symptoms related to bowel function in 62 women with pelvic organ prolapse. When asked whether they were bothered by their bowel function, women responded on a scale from 1 (not at all) to 10 (extremely bothered).

Values are Spearman's correlation coefficient. Significant associations are in boldface with $\mathrm{p}$ value in parentheses.
Table 4: Bowel symptom responses from pop-q in symptomatic women.

\begin{tabular}{|c|c|c|c|}
\hline $\begin{array}{l}\text { Bowel } \\
\text { symptoms }\end{array}$ & Response & $\begin{array}{l}\text { Symptomatic } \\
(\mathrm{n}=62)\end{array}$ & $\%$ \\
\hline \multirow{4}{*}{$\begin{array}{l}\text { Incomplete } \\
\text { defeacation }\end{array}$} & Not at all & 44 & 71 \\
\hline & A little & 10 & 16.1 \\
\hline & Moderately & 6 & 9.6 \\
\hline & A lot & 2 & 3.2 \\
\hline \multirow{4}{*}{ Constipation } & Not at all & 42 & 67.7 \\
\hline & A little & 19 & 30.6 \\
\hline & Moderately & 0 & 0 \\
\hline & A lot & 1 & 1.6 \\
\hline \multirow{4}{*}{$\begin{array}{l}\text { Empty your } \\
\text { bowel with } \\
\text { finger }\end{array}$} & Not at all & 48 & 77.4 \\
\hline & A little & 9 & 14.5 \\
\hline & Moderately & 4 & 6.4 \\
\hline & A lot & 1 & 1.6 \\
\hline \multirow{4}{*}{$\begin{array}{l}\text { Frequency of } \\
\text { stool }\end{array}$} & $\begin{array}{l}>=\text { once a } \\
\text { day }\end{array}$ & 51 & 82.3 \\
\hline & $\begin{array}{l}\text { Once every } \\
2 \text { days }\end{array}$ & 8 & 13 \\
\hline & $\begin{array}{l}\text { Once every } \\
3 \text { days }\end{array}$ & 2 & 3.2 \\
\hline & $\begin{array}{l}\text { Once a } \\
\text { week or > }\end{array}$ & 1 & 1.6 \\
\hline \multirow{4}{*}{$\begin{array}{l}\text { Faecal } \\
\text { incontinence }\end{array}$} & Not at all & 62 & 100 \\
\hline & A little & 0 & 0 \\
\hline & Moderately & 0 & 0 \\
\hline & A lot & 0 & 0 \\
\hline \multirow{4}{*}{$\begin{array}{l}\text { Gaseous } \\
\text { incontinence }\end{array}$} & Not at all & 57 & 91.9 \\
\hline & A little & 3 & 4.8 \\
\hline & Moderately & 2 & 3.2 \\
\hline & A lot & 0 & 0 \\
\hline
\end{tabular}

Table 5: Correlations between bowel symptoms and pop-q measurements among symptomatic women.

\begin{tabular}{|c|c|c|c|c|c|}
\hline \multirow{2}{*}{$\begin{array}{l}\text { POP-Q } \\
\text { domain } \\
\text { symptoms }\end{array}$} & \multirow[b]{2}{*}{ Aa } & POP-Q & \multicolumn{2}{|c|}{ Points } & \multirow[b]{2}{*}{ Bp } \\
\hline & & $\mathbf{B a}$ & $\mathbf{C}$ & Ap & \\
\hline $\begin{array}{l}\text { Incomplete } \\
\text { defecation }\end{array}$ & 0.01 & 0.02 & 0.04 & 0.11 & 0.11 \\
\hline Constipation & 0.08 & 0.08 & 0.16 & 0.01 & 0.01 \\
\hline $\begin{array}{l}\text { Empty your } \\
\text { bowels with } \\
\text { your finger }\end{array}$ & 0.08 & 0.04 & 0.02 & 0.19 & 0.21 \\
\hline $\begin{array}{l}\text { Frequency of } \\
\text { stool }\end{array}$ & 0.08 & 0.15 & 0.07 & 0.03 & 0.16 \\
\hline $\begin{array}{l}\text { Faecal } \\
\text { incontinence }\end{array}$ & 0.05 & 0.08 & 0.18 & 0.10 & 0.03 \\
\hline $\begin{array}{l}\text { Gaseous } \\
\text { incontinence }\end{array}$ & 0.14 & 0.23 & 0.23 & 0.02 & 0.09 \\
\hline
\end{tabular}

\section{DISCUSSION}

Margie reported weak correlation between protrusion symptoms and bowel symptoms. ${ }^{9}$ Straining at stool remain associated with anterior wall and perineal descent. Annette observed that stage of pop and specific prolapsed 
symptoms are associated, but strong association does not exist between POP and bowel symptoms. ${ }^{10}$ Allesandero noted stronger relationship between posterior wall prolapse and bowel complains than anterior prolapsed and urinary complains. ${ }^{11}$ Weber $A$ found that women with prolapse have bowel symptoms but these are not correlated with severity of posterior vaginal wall prolapse. $^{12}$

Present study reveals that women with prolapse have bowel symptoms, but they are not correlated with severity of posterior vaginal wall descent. Hence before subjecting patient to any operative procedure, she should be thoroughly evaluated as to cause of symptoms as they may persist postoperative.

Further studies regarding operative procedure if done and relief of symptoms need to be carried out to resolve the issue.

\section{CONCLUSION}

Women with uterovaginal prolapse frequently have symptoms related to bowel dysfunction but this is not associated with the severity of posterior vaginal prolapse.

Funding: No funding sources

Conflict of interest: None declared

Ethical approval: The study was approved by the Institutional Ethics Committee

\section{REFERENCES}

1. Samuelsson E, Victor AF, Tibblin G, Svärdsudd K. Signs of genital prolapse in a Swedish population of women 20 to 59 years of age and possible related factors. Am J Obstet Gynecol. 1999;180(2):299-305.

2. Progetto Menopausa Italia Study Group. Risk factors for genital prolapse in non-hysterectomized women around menopause-results from a large crosssectional study in menopausal clinics in Italy. European J Obstet Gynecol. 2000;2(93):135-40.

3. Olsen AL, Smith VJ, Bergstrom JO, Colling JC, Clark AL. Epidemiology of surgically managed pelvic organ prolapse and urinary incontinence. Obstet Gynecol. 1997 Apr 1;89(4):501-6.

4. Bump R, Mattiasson A, Bø K, Brubaker L, DeLancey J, Klarskov P et al. The standardization of terminology of female pelvic organ prolapse and pelvic floor dysfunction. Am J Obstet Gynecol. 1996;175(1):10-7.

5. Hall A, Theofrastous J, Cundiff G, Harris R, Hamilton L, Swift $S$ et al. Interobserver and intraobserver reliability of the proposed International Continence Society, Society of Gynecologic Surgeons, and American Urogynecologic Society pelvic organ prolapse classification system. Am J Obstet Gynecol. 1996;175(6):1467-71.

6. Abrams P, Cardozo L, Fall M, Griffiths D, Rosier P, Ulmsten $U$ et al. The standardisation of terminology of lower urinary tract function: Report from the standardisation sub-committee of the International Continence Society. Neurourol Urodynamics. 2002;21(2):167-78.

7. Bland D, Earle B, Vitolins M, Burke G. Use of the Pelvic Organ Prolapse staging system of the International Continence Society, American Urogynecologic Society, and Society of Gynecologic Surgeons in perimenopausal women. Am J Obstet Gynecol. 1999;181(6):1324-8.

8. Muir T, Stepp K, Barber M. Adoption of the pelvic organ prolapse quantification system in peerreviewed literature. Am J Obstet Gynecol. 2003;189(6):1632-5.

9. Kahn MA. Pelvic Organ Support Study (POSST) and bowel symptoms: Straining at stool is associated with perineal and anterior vaginal descent in a general gynecologic population. Am J Obstet Gynecol. 2005;192(5):1516-22.

10. Groenendijk AG, Birnie E, Roovers JP, Bonsel GJ. Contribution of primary pelvic organ prolapse to micturition and defecation symptoms. Obstet Gynecol Int. 2011;2012:1-9.

11. Digesu GA, Chaliha C, Salvatore S, Hutchings A, Khullar V. The relationship of vaginal prolapse severity tosymptoms and quality of life. BJOG: An Int J Obstet Gynaecol. 2005;112(7):971-6.

12. Weber AM, Walters MD, Ballard LA, Booher DL, Piedmonte MR. Posterior vaginal prolapse and bowel function. AJOG. 1998;179(6):1446-50.

Cite this article as: Bijwe SA, Rajbhara P. Study of posterior vaginal wall prolapses and correlation with bowel function. Int J Reprod Contracept Obstet Gynecol 2017;6:3143-6. 